Dept. of Animal Hygiene and Zoonoses,

Fac. Vet. Medicine, Assiut Univ.

\title{
A STUDY ON H. PYLORI AND H. HEILMANNII IN MILK, SOFT CHEESE AND THE HEALTH HAZARD ON CHILDREN IN ASSIUT GOVERNORATE
}

(With 3 Tables and 3 Figures)

\author{
By \\ AMAL S.M. SAYED; ASMAA A. HUSSEIN; \\ MONA A. HASSAN*; SALWA SEIF EL DIN*; \\ EMAN AHMED M.M** and HANAN A. NOAMAN*** \\ * Dept. of Microbiology and Immunology, Fac. Medicine, Assiut Univ. \\ ** Dept. of Pathology, Fac. Medicine, Assiut Univ. \\ *** Dept. of Pediatrics, Fac. of Medicine, Assiut Univ.
}

(Received at 8/5/2010)

دراسة عن H. pylori و ف H. heilmannii في اللبن والجبن والخطورة الصحية على الأطفال فى محافظة أسيوط

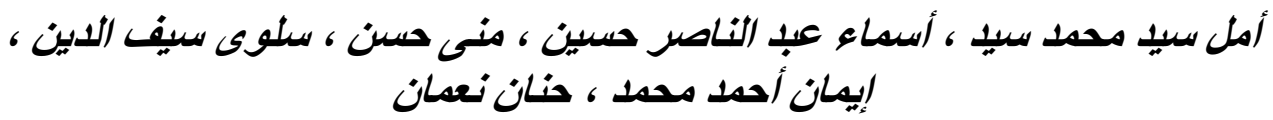

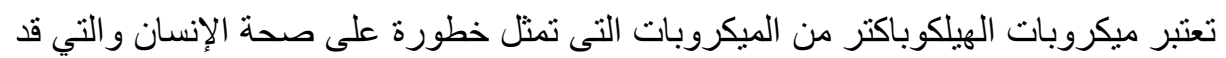

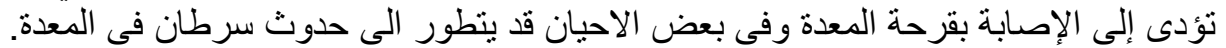

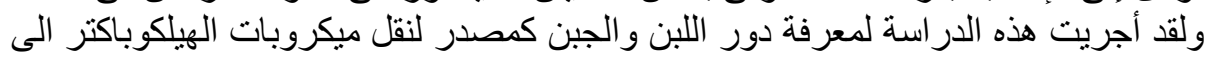

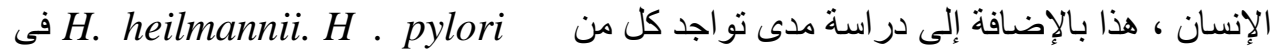

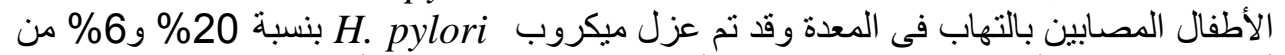

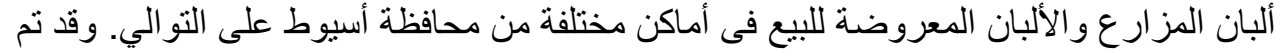

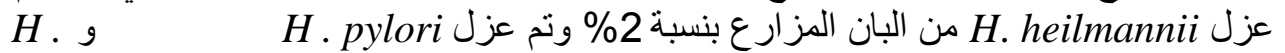

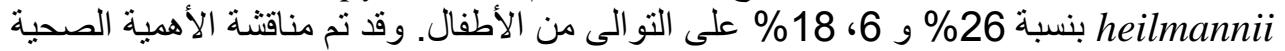

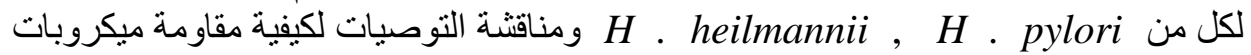

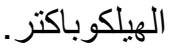

\section{SUMMARY}

Helicobacter microorganisms are considered one of the important zoonotic microorganisms with public health hazard leading to gastric ulcer which may progress to gastric cancer. This study was designed to elucidate whether raw milk and soft cheese can act as a source of Helicobacter 
infection to man. Moreover, investigation was carried out to determine the incidence rate of $H$. pylori and $H$. heilmannii among children suffering from gastric diseases. H. pylori was isolated from $20 \%$ and $6 \%$ of the examined milk from dairy farms and dairy shops, respectively. $H$. heilmannii was isolated from $2 \%$ of farm milk. $H$. pylori and H. heilmannii were isolated from $26 \%$ and $8 \%$ of the examined children, respectively. In conclusion, milk may act as a vehicle of $H$. pylori and $H$. heilmannii and pose a health hazard to man. It is recommended to begin treatment early in patients with gastritis to accelerate healing and prevents ulcer production.

Key words: H. pylori, H. heilmannii, milk, human, polymerase chain reaction, stool antigen.

\section{INTRODUCTION}

Helicobacter species are wide spread micro-organisms and have been isolated from the gastric mucosa of a wide variety of wild and domestic mammals as well as humans (Gueneau et al., 2002). Although transmission pathways of Helicobacter microorganisms to human are still unclear, several routes of transmission have been suggested (Allaker et al., 2002). Helicobacter microorganisms are transmitted from animals to man either through fecal oral transmission or consumption food of animal origin especially, milk and milk products (Van Duynhoven and de Jonge, 2001; Fujimura et al., 2002; Roma-Giannikou et al., 2002).

$H$. pylori is considered as the major agent of causing chronic gastritis worldwide and infects approximately one-half of the world's population (Everhart, 2000). Helicobacter heilmannii, has also been implicated as a potential cause of gastric disease in humans and rarely reported in children (Solnick et al., 1993). Infection with H. heilmannii is thought to be considerably less frequent than infection with $H$. pylori (Fawcett et al., 1999). Helicobacter infection in man may be asymptomatic (Parsonnet, 1998) however; it may cause chronic gastritis, gastric ulcer and duodenal ulcer (Ozturk, et al., 1996). Infection with Helicobacter species are strongly linked to development of gastric carcinoma and gastric B-cell lymphoma (Suerbaum and Michetti, 2002).

There are several methods for detecting the presence of Helicobacter infection, each having its own advantages and disadvantages. Basically these tests are classified into two categories depending on whether endoscope biopsy is necessary. Histological evaluation, culture, polymerase chain reaction (PCR) and rapid urease tests are typically 
performed on tissue obtained at endoscopy. Alternatively simple breath test, serology and stool assay are used without the need of biopsy (Bravos and Gilman. 2000).

This study was designed to elucidate the role of raw milk and soft cheese as a source of Helicobacter infection to man. On the other hand, investigation was carried out to determine the prevalence of $H$. pylori and $H$. heilmannii among children suffering from gastric diseases. The study was carried out in the period from May 2007 to April 2008.

\section{MATERIALS and METHODS}

\section{Milk and cheese samples:}

150 samples of raw milk from dairy farms, dairy shops and soft cheese $(50$ each) were collected randomly from different geographical regions in Assiut Governorate.

\section{Children:}

The study included 50 children (2-15years) with symptoms of persistence or recurrent upper abdominal discomfort including nausea, vomiting, haematemesis, heartburn and bloating or early satiety examined at gastroenterology unit of Assiut children university hospital. Informed consent of parents was obtained before enrollment in the study.

\section{Exclusion criteria:}

Children who had taken antimicrobials, antacids, H2 blockers, proton pump inhibitors, or bismuth sub salicylate within the 4weeks prior to endoscopy were excluded from the study. Two gastric biopsy samples were obtained from the antrum of each patient. One of the biopsy samples was fixed in $10 \%$ buffered formalin and embedded in paraffin for histopathological examination. The other biopsy was stored in normal saline on ice for bacteriological isolation.

\section{Histological examination:}

The paraffin embedded samples were cut at $5 \mu \mathrm{g}$ and the sections were stained with modified Giemsa and examined with light microscopy. All sections were examined to detect the grading of gastritis and the presence or absence of $H$. pylori and $H$. heilmannii. H. heilmannii is a spiral 7-10 $\mu \mathrm{m}$ (Oliva et al., 1993) whereas, H. pylori is a small, curved bacteria 2-5 $\mu \mathrm{m}$ (Marshall, 1983). Bacterial distribution was assessed by the number of colonized crypts. Mild abundance is considered when, Helicobacter organisms found only in one crypt, moderate abundance is considered when, several crypts were colonized with the organisms and severe abundance is considered when both crypts and surface epithelium were colonized. 


\section{Bacteriological isolation: \\ Enrichment:}

Gastric mucosal biopsy specimens were minced in saline with a sterile glass rod. A drop of the material was transferred to the selective enrichment broth for Helicobacter.

$1 \mathrm{ml}$ of each milk sample or $1 \mathrm{~g}$ of each cheese sample was transferred to selective enrichment broth for Helicobacter $(H$. pylori special peptone broth) which was supplemented with vancomycin $10 \mathrm{mg}$ /litre, amphotercin B sulphate $31.000 \mathrm{IU} /$ litre trimethoprim 40mg /litre and calf serum (Stevenson et al., 2000). The inoculated broth was incubated under microaerophilic condition $(6 \% \mathrm{O} 2,10 \% \mathrm{CO} 2$ and $84 \% \mathrm{~N} 2)$ at $37^{\circ} \mathrm{C}$ for $48 \mathrm{~h}$.

\section{Isolation and Identification:}

Loopful of the incubated broth was streaked onto plates of $H$. pylori special peptone agar media (HPSPA) and incubated at $37^{\circ} \mathrm{C}$ for 4 days under microaerophilic condition (6\% O2, $10 \% \quad \mathrm{CO} 2$ and $84 \% \mathrm{~N} 2)$. Suspected colonies were maintained on HPSPA slants for further identification. Colonies were identified on the basis of their colony morphology, Gram staining and positive reaction with urease, catalase and oxidase (Fox et al., 2000). Suspected colonies of $H$. heilmannii were maintained on HPSA slants for further identification with PCR.

\section{DNA extraction and amplification:}

DNA of the suspected colonies of $H$. heilmannii was extracted by using Guanidium thiocynate (Boom et al., 1990). H.heimannii urease B gene was amplified by using primers

F 5'-GGGCGATAAAGTGCGCTTG-3' and

R 5'CTGGTCAATGAGAGCAGG -3' (Neiger et al., 1998). Amplification was performed in a total volume of $25 \mu \mathrm{l}$ containing $2 \mu \mathrm{l}$ of DNA extracts of each colony, 100pmol of each primer. The PCR was conducted in a Biometra Thermal cycler (Biometra - Germany) and the amplification condition was one cycle of $94^{\circ} \mathrm{C}$ for $30 \mathrm{~min}, 72^{\circ} \mathrm{C}$ for $3 \mathrm{~min}$, followed by $31 \mathrm{cycles}$ of $94^{\circ} \mathrm{C}$ for $30 \mathrm{sec}, 57^{\circ} \mathrm{C}$ for $3 \mathrm{sec}$, and $72^{\circ} \mathrm{C}$ for $1 \mathrm{~min}$ and final extension at $72^{\circ} \mathrm{C}$ for one min. PCR products $(10 \mu \mathrm{l})$ were analyzed by electrophoreses on $2 \%$ agarose gel containing ethidium bromide and visualized under UV illumination. PCR product size is 580 bp (Figure 1).

\section{$H$. pylori stool antigen test:}

Stool sample of each patient was collected and transported directly to the lab and stored at $-20^{\circ} \mathrm{C}$ until processed. Qualitative enzyme linked immunosorbent assay (Astra s.r.l Via Ciro Menotti 1/A 20129 Milano) (www.astradiagnostici.com) was used to detect the presence of $\mathrm{H}$. pylori 
antigens in the stool. The protocol was followed according to manufacturer's procedure.

\section{RESULTS}

Table 1: Incidence of Helicobacter species in the examined samples

\begin{tabular}{|l|c|c|c|c|c|c|c|c|}
\hline $\begin{array}{c}\text { Helicobacter } \\
\text { species }\end{array}$ & \multicolumn{7}{|c|}{ Source of Samples } \\
\hline & Farm milk & \multicolumn{2}{|c|}{ Dairy shops } & Cheese & \multicolumn{2}{c|}{ Human } \\
\hline & No. & $\%$ & No. & $\%$ & No. & $\%$ & No. & $\%$ \\
\hline H. pylori & 10 & 20 & 3 & 6 & - & - & 13 & 26 \\
\hline H. heilmannii & 1 & 2 & 1 & 2 & - & - & 4 & 8 \\
\hline Total & 11 & 22 & 4 & 8 & - & - & 17 & 34 \\
\hline
\end{tabular}

Table 2: Detection of $H$. pylori in children by different methods

\begin{tabular}{|c|c|c|c|c|c|}
\hline \multicolumn{2}{|c|}{ Bacterial isolation } & \multicolumn{2}{|c|}{ Stool antigen } & \multicolumn{2}{c|}{ Histopathology } \\
\hline No. & $\%$ & No. & $\%$ & No. & $\%$ \\
\hline 13 & 26 & 13 & 26 & 13 & 26 \\
\hline
\end{tabular}

Table 3: Correlation between the endoscopic findings and the existence of H. pylori and H. heilmannii

\begin{tabular}{|l|c|c|c|}
\hline Endoscope findings & No./50 & H. pylori & H. heilmannii \\
\hline Gastritis grade I & 19 & $6(31.58 \%)$ & $2(10.53 \%)$ \\
\hline Gastritis grade II & 6 & $2(33.33 \%)$ & $1(16.67 \%)$ \\
\hline Gastritis grade III & 3 & $2(66.67 \%)$ & - \\
\hline *Total & 28 & $10(35.71 \%)$ & $3(10.71 \%)$ \\
\hline Gastric ulcer & 1 & $1(100 \%)$ & - \\
\hline Normal & 21 & $2(9.52 \%)$ & $1(4.76 \%)$ \\
\hline
\end{tabular}

Gastritis grade I: some hyperemia in the gastric mucosa.

Gastritis grade II: Mosiac hyperemia in the gastric mucosa.

Gastritis grade III: Coublestone appearance of gastric mucosa.

*chronic active gastritis: grade I, grade II, grade III 
Figure1: PCR identification of $H$. heilmannii

$\mathrm{M}$ marker, lanes 1, 3, 4, 5, 6, $7 \mathrm{H}$. heilmannii isolated strains lanes: 2, 8 negative samples.

Human strains 1,3,4,5. Milk strains:6, 7.

Figure : 2 Giemsa stained H. pylori organisms in gastric biopsy 
Figure : 3 Giemsa stained $H$. heilmannii organisms in gastric biopsy

\section{DISCUSSION}

Epidemiological investigation revealed that food especially of animal origin play an important role in transmission of Helicobacter infection to man (Gomes and De Martinis, 2004). Although milk is not likely to contain Helicobacter organisms, it is considered as a source of infection after external contamination from the surrounding environment (Bohmeler et al., 1996). Helicobacter species were isolated from $22 \%$ of milk samples obtained from dairy farms and $8 \%$ of milk samples obtained from dairy shops (Table 1). We could not isolate Helicobacter species from cheese. H. pylori was isolated from milk of farms and dairy shops with a rate of $20 \%$ and $6 \%$, respectively (Table 1). Higher prevalence rates (72.2\%) and (50\%) of $\mathrm{H}$. pylori were reported in cow's milk, respectively (Fujimura et al., 2002; Quaglia et al., 2008). Several investigators had incriminated milk as a vehicle of $H$. pylori transmission (Fan et al., 1998; Fujimura et al., 2002 \& Van Duynhoven and de Jonge, 2001). It has been reported that $H$. pylori can survive in milk for up to 10 days at $4{ }^{\circ} \mathrm{C}$ storage (Fan et al., 1998). However, other studies failed to detect $H$. pylori in milk (Poms and Tatini 2001; Jiang and Doyle, 2002).

$H$. heilmannii was isolated from $2 \%$ of milk from dairy farms and dairy shops (Table 1). Although no data is available in the literature about the isolation of $H$. heilmannii from milk, our result is not unpredictable as once contamination of milk occur, $H$. heilmannii can be detected. It has been suggested that $H$. heilmannii infection in human is a zoonosis and 
animals serve as reservoirs for transmission to humans (Meining et al., 1998).

Helicobacter species were isolated from $17(34 \%)$ of the examined human biopsy with a rate of $26 \%$ for $\mathrm{H}$. pylori and $8 \%$ for $\mathrm{H}$. heilmannii (Table 1). The prevalence rate of $H$. pylori and $H$. heilmannii obtained in this study among the examined children is considered within the range reported in the developing world and the previous research reported in Egypt (Bassily et al., 1999; Naficy et al., 2000). Higher prevalence rates of H. pylori (48\% and 46\%) were reported, respectively (Clemens et al., 1996; Sherif et al., 2004). However, lower prevalence rate (8.9\%) was reported in another study (Karine et al., 1999).

Concerning $H$. heilmannii isolation, lower prevalence rate $(0.4 \%)$ was obtained previously (Karine et al., 1999). It has been also reported that the prevalence rate of $\mathrm{H}$. heilmannii in humans varies from $0.5 \%$ to $6 \%$ (Wooten et al., 2004). Moreover, it has been reported that $H$. heilmannii accounts for $0.2 \%$ to $0.4 \%$ of human gastritis cases (Solnick et al., 1993). On the other hand it has been reported that the frequency of $H$. heilmannii infection ranged from $0.25 \%$ to $1.2 \%-1.7 \%$ (Heilman and Borchard, 1991; Kubonovak et al., 1994; Yang et al., 1995). The variable rates of Helicobacter isolation in different studies vary greatly, depending on the location of study group and the characteristics of the population studied. Generally, prevalence of Helicobacter infection correlates positively with low socioeconomic status and increases with age (Malaty and Graham 1994).

On histopathological examination of the biopsy samples, $10(35.71 \%)$ and $1(100 \%)$ of the samples showed $H$. pylori associated with chronic active gastritis and gastric ulcer, respectively (Table 3). On the other hand $3(10.71 \%)$ of biopsy samples showed long spiral organisms corresponding to $H$. heilmannii and were associated with chronic active gastritis (Table 3). Heilcobacter organisms were demonstrated either in the mucus or on the cell surface (Figure: 2 and 3). Although Helicobacter species were isolated from patients with different grades of gastritis on endoscopy, it has been also isolated from patients, with normal gastric mucosa with a percentage of $9.52 \%$ for $H$. pylori and $4.76 \%$ for $H$. heilmannii (Table 3). Our findings are in concurrence with that previously reported (Hassall and Dimmick 1991). H. pylori infection like other bacteria can induce an inflammatory process in the tissue. The organism is found in the lamina propria that indicates the organisms invade the gastric mucosa and this can explain why the organism escapes from eradication. There are some mediators that help in inflammation like IL2, IL7 and TNFoxidative radicals by monocytes and macrophages (Glassman 1992). 
Histopathological examination of the biopsy samples reveals that colonization of $H$. pylori was detected with moderate to severe density on the surface epithelium and within the crypts. In contrast $H$. heilmannii was detected with mild to moderate density in one crypt or several crypts, but no colonization of the surface epithelium was observed. Our result is in concurrence with that previously reported (Karine et al., 1999).Our data show that the patchy distribution of $H$. heilmannii was found in the antrum and this result is concurrent with another study (Karine et al., 1999). Moreover, it has been described that the distribution of $H$. heilmannii was more frequently in the antrum in contrast to $H$. pylori, which was often present in both the antrum and fundus (Wooten et al., 2004). Neither atrophy nor metaplasia was observed in the examined biopsy samples of $H$. pylori and $H$. heilmannii. Similar results were described in the literature (Heilmann and Borchard 1991; Oliva et al., 1993).

Although histopathology is considered the most reliable method to diagnose Helicobacter infection (Drumm et al., 2000; Gold et al., 2000), stool antigen test was accepted by clinical researchers and by community physicians as it provides an easy method for epidemiological investigation as well as for clinical diagnosis (Elitsur, 2005). In our study we could detect the same infection rate (26\%) by using different methods, including bacterial isolation, histopathology and stool antigen test (Table 2).

In conclusion, results obtained in this study reveal that milk may act as a vehicle of $H$. pylori and $H$. heilmannii which pose a public health hazard. Careful sanitary measures coupled with personal hygiene should be applied in farms as well as during milk processing to improve the microbiological safety of milk and milk products. Diagnosis of $H$. heilmannii infection are usually difficult because of its sparseness and patchy distribution so, we suggest that it is important to look carefully for $H$. heilmannii at histological examination especially in the cases of $H$. pylori negative gastritis in children. It is recommended to begin treatment early to accelerate healing and prevents long term ulcer production. Therapy should include a gastric acid production blocker (histamine h2 blocker or proton- pump inhibitor) together with two antibiotics (sulfamethoxazole and amoxicillin) for at least 3 months.

\section{REFERENCES}

Allaker, KA.; Young, JM.; Hardie, Domizio, P. and Meadows, NJ. (2002): Prevalence of Helicobacter pylori at oral and gastrointestinal sites in children: evidence for possible oral-to-oral transmission, J Med Microbiol. 51: 312-317. 
Bassily, S.; Frenck, RW.; Mohareb, EW.; Wierzba, T.; Savarino, S.; Hall, E.; Kotkat, A.; Naficy, A.; Hyams, KC. and Clemens, J. (1999): Seroprevalence of Helicobacter pylori among Egyptian newborns and their mothers: a preliminary report. Am J Trop Med Hyg. 61: 37- 40.

Bohmeler, G.; Gerwert, J.; Scupin, E. and Sinell, HJ. (1996): Epidemiology of $H$. pylori in man: studies on survival of the agent in food. Dtsch Tieraztl Wschr 103: 438-443.

Boom, R.; Sol, CJA.; Salimans, MMM.; Jansen, CL.; Wertheim van Dillen, PME. and Van der Noordaa, J. (1990): Rapid and simple method for purification of nucleic acids. J Clin Microbiol., 28: 495-503.

Bravos, ED. and Gilman, RH. (2000): Accurate diagnosis of Helicobacter pylori. Other tests. Gastroenterol Clin North Am. 29: 925-929.

Clemens, J.; John, AM.; Meng, RM.; Shamshul, H.; Firdausi, Q.; Frederick, Van Loon, Bodrul, P; Abdollah, N. and Arabinda, B. (1996): Sociodemographic, hygienic and nutritional correlates of Helicobacter pylori infection of young Bangladeshi children. Pediat Infect Dis. (15)12: 1113-1118.

Drumm, B.; Koletzkko, S. and Oderda, G. (2000): Helicobacter pylori infection in children: a consensus statement. Am J. Pediatr Gastroenterol Nut. 30: 207-213.

Elitsur, Y. (2005): Helicobacter pylori diagnostic tools: Is it in the stool? J of Pediatr. 146: 164-167.

Everhart, JE. (2000): Recent developments in the epidemiology of Helicobacter pylori infection. Gastroenterol Clin N Amer. 29: 559-578.

Fan, XG.; Chua, A.; Li, TG. and Zeng, QS. (1998): Survival of Helicobacter pylori in milk and tap water. J. Gastroenterol Hepatol. 11: 1096-1098.

Fawcett, PT.; Gibney, KM. and Vinete, KMB. (1999): Helicobacter pylori can be induced to assume the morphology of Helicobacter heilmannii. J. Clin Microbiol. 37: 1045-1048.

Fox, JG.; Chein, CC.; Dewhirst, FE.; Paster, BJ.; Shein, Z.; Melito, PL.; Woodward, DL. and Redgers, FG. (2000): Helicobacter canadensis sp. Nov. isolated from humans with diarrhea as an example of an emerging pathogen. J. Clin Microbiol. 38(7): 2546-2549.

Fujimura, S.; Kawamura, T.; Kato, S.; Tateno, H. and Watanabe, A. (2002): Detection of Helicobacter pylori in cow's milk. Letters in Appl Microbiol. 35: 504-507. 
Glassman, MS. (1992): Helicobacter pylori infection in children. A clinical overview. Clin Pediatr. 8:481- 487.

Gold, BD.; Colletti, RB.; Abott, M.; Czinn, SJ.; Elitsur, Y. and Hassal, E. et al. (2000): Helicobacter pylori infection in children: recommendation for diagnosis and treatment: a medical position statement of the North American society for Pediatric Gastroenterology and Nutrition. J. Pediatr Gastroenter and Nut. 31: 490-497.

Gomes, BC. and De Martinis, ECP. (2004): The significance of Helicobacter pylori in water, food and environmental samples. Food Control 15: 397-403.

Gueneau, P.; Fuenmayor, J.; Aristimuno, OC.; Cedeno, S.; Baez, E.; Reyers, N.; Michelangeli, F. and Dominguez-Bello, MG. (2002): Are goats naturally resistant to gastric Helicobacter infection? Vet. Microbiol. 84(1-2): 115-121.

Hassall, E. and Dimmick, JE. (1991): Unique features of Helicobacter pylori disease in children. Dig Dis Sci. 36: 417.

Heilmann, KL. and Borchard, F. (1991): Gastritis due to spiral shaped bacteria other than Helicobacter pylori.Clinical, histological and ultrastructural findings. Gut 32: 137-140.

Jiang, X. and Doyle, MP. (2002): Optimizing enrichment culture conditions for detecting $H$. pylori in foods. J. Food Prot. 65: 1949-1954

Karine, M.; Laurent, M.; Dominique, G.; Deasalle, EM.; Pascal, V.; Dominque, T. and Frederic, G. (1999): Characteristics and prevalence of Helicobacter heilmannii infection in children undergoing upper gastrointestinal endoscopy. J. Pediatr Gastroenter and Nut. 29(5): 533-539.

Kubonovak, K.; Trpi, J.; Jancula, L.; Polak, E. and Vrablik, V. (1994): Presence of spiral bacteria (Gastrospirillum hominis) in the gastric mucosa. Eur J Clin Microbiol Infect Dis. 10: 459-460.

Malaty, HM. and Graham, DY. (1994): Importance of childhood socioeconomic status on the current prevalence of Helicobacter pylori infection. Gut 35: 742-745.

Marshall, BJ. (1983): Unidentified curved bacilli on gastric epithelium in active chronic gastritis. Lancet 1273-1275.

Meining, AKroher, G. and Stolte, M. (1998): Animal reservoirs in the transmission of Helicobacter heilmannii. Results of a questionnaire- based study. Scand J Gastroenterol. 33 (8): 795-798. 
Naficy, AB.; Frenck, RW.; Abu-Elyazeed, R.; Kim, Y.; Rao, MR.; Savarino, SJ.; Wierzba, TF.; Hall, E. and Clemens, JD. (2000): Seroepidemiology of Helicobacter pylori infection in a population of Egyptian children. Int J Epidemiol. 29: 928- 932

Neiger, R.; Dieterich, C.; Burnens, A.; Waldvogel, A.; Corthesy-Theulaz,

I.; Halter, F.; Lauterburg, B. and Sehmassmann, A. (1998):

Detection and prevalence of Helicobacter infection in pet cats. $\mathbf{J}$ Clin Microbiol. 36(3):634-637.

Oliva, MM.; Lazenby, AJ. and Perman, JA. (1993): Gastritis associated with Gastropirillum hominis in children. Comparison with Helicobacter pylori and review of the literature. Mod Pathol. 6:513- 515.

Ozturk, H.; Senocak, ME.; Uzunalimoglu, B.; Hascelik, G.; Buyukpamukcu, N. and Hicsonmez, A. (1996): Helicobacter pylori infection in symptomatic and asymptomatic children: a prospective clinical study. Eur. J. Pediat Surg. 6: 265-269.

Parsonnet, J.; Helicobacter pylori. Infect Dis Clin N Am. (1998): 12: 185-197.

Poms, RE. and Tatini, SR. (2001): Survival of Helicobacter pylori in ready-to-eat foods at $4{ }^{\circ} \mathrm{C}$. Int. J. Food Microbiol. 63: 281-286.

Quaglia, NC.; Dambrosio, A.; Normanno, G.; Parisi, A.; Patrono, R.; Ranieri, G.; Rella, A. and Celano, GV. (2008): High occurrence of Helicobacter pylori in raw goat, sheep and cow milk inferred by glm M. gene: A. risk of food-borne infection? Int. J Food Microbiol. 10: 124(1):43-47

Roma-Giannikou, E.; Karameris, A.; Balatsos, B.; Panayiotou, J.; Manika, Z.; Vliet, Van- C.; Rokkas, T.; Skandalis, N. and Kattamis, C. (2002): Interfamilial spread of Helicobacter pylori: A genetic analysis. In: European Helicobacter Study Group, Abstract from Athens Workshop 2002. XV International Workshop, September 11-14. Available at www.helicobacter.org.

Sherif, M.; Mohran, Z.; Fathy, H.; Rockabrand, DM.; Rozmajz, PJ. and Frenck, $R W$. (2004): Universal high-level primary Metronidazole resistance in Helicobacter pylori isolated from children in Egypt. J Clin Microbiol. 42(10) 4832-4834

Solnick, JV.; Rourke, J.; Lee, A.; Paster, B.; Dewhirst, F. and Tompkins, L. (1993): An uncultured gastric spiral organism is a newly identified Helicobacter in humans. J Infect Dis. 168: 379-385.

Stevenson, TH.; Lucia, LM. and Acuff, GR. (2000): Development of a selective medium for isolation of Helicobacter pylori from cattle and beef samples. Appl Environ Microbiol. 66(2): 723-727. 
Suerbaum, S. and Michetti, P. (2002): Helicobacter pylori infections. N Engl. J. Med. 347: 1175-1186.

Wooten, DC.; Rakheja, D. and Timmons, CF. (2004): Helicobacter heilmannii infection in a child. Arch Pathol Lab Med. 128: 14661-1462.

Van Duynhoven, $R$. and de Jonge YT. Transmission of Helicobacter pylori: a role for food? (2001): Bull World Health Organ. 79: 455-459.

Yang, H.; Li, X.; Xu, Z. and Zhou, D. (1995): Helicobacter heilmannii infection in a patient with gastric cancer. Dig Dis Sci. 40: 1013-1014. 